\title{
INFLUENCES OF HYGIENE PRACTICES, AWARENESS AND INVOLVEMENT LEVELS ON ENVIRONMENTAL HYGIENE AMONG UMT STUDENTS
}

\author{
NUR SYUHADA IBRAHIM, ZIKRI MUHAMMAD*, AND JUMADIL SAPUTRA \\ School of Social and Economic Development, Universiti Malaysia Terengganu, Kuala Terengganu, Malaysia \\ *Corresponding author: zikri@umt.edu.my
}

\begin{abstract}
Industrial development plays the most important role in the degradation of the global environment. In line with this issue, most universities in the world have introduced environmental management to increase awareness among young generation towards the environment. Therefore, this study is employed to examine the influences of hygiene practices, awareness and involvement levels towards environmental hygiene among UMT students. The design of this study is quantitative using cross-sectional data collected from students at residential colleges in Universiti Malaysia Terengganu. A total of 120 respondents participated but only data from 100 students could be used for further analysis after the data screening process. The result of this study showed that the level of awareness of UMT students on environmental issues could be categorized as moderate. Besides that, this study found that the level of awareness had significant positive influences on environmental hygiene. Meanwhile, hygiene practices and the level of involvement did not have significant influences on environmental hygiene. In addition, using the findings of this study, we suggest that the stakeholders of UMT increase the hygiene practice and involvement among young generation to increase the level of awareness regarding environmental hygiene.
\end{abstract}

Keywords: Hygiene Practices, Awareness and Involvement Levels, Environmental Hygiene

\section{Introduction}

Nowadays, the development of industrialization economic has been causing environmental degradation around the world (Dincer, 2000). The environment pollution is one of the major issues due to waste production by human activities (Omer, 2008). In Malaysia, the environmental awareness among community has been increasing in the past several years.
However, the awareness and involvement levels relating the environmental management and its components are still at a lower level. The SWCorp (2016) reported that $1,981.44$ tons of solid waste could be recycled in 2016 . Table 1 displays the total recyclable waste by state in 2016. Imagine what will happen when the waste is not properly managed. How will people continue their lives? Therefore, society's attitude towards environmental hygiene needs to be studied. 
Table 1: Waste Collection at 8 (eight) States, Malaysia in 2016

\begin{tabular}{lccccccccc}
\hline \multirow{2}{*}{ Month } & \multicolumn{9}{c}{ State (in Tan) } \\
\cline { 2 - 8 } & WP.KL & $\begin{array}{c}\text { Putrajay } \\
\mathbf{a}\end{array}$ & $\begin{array}{c}\text { Pahan } \\
\mathbf{g}\end{array}$ & Perlis & $\begin{array}{c}\text { Keda } \\
\mathbf{h}\end{array}$ & $\begin{array}{c}\text { N. } \\
\text { Sembilan }\end{array}$ & $\begin{array}{c}\text { Melaka } \\
\text { Joho } \\
\mathbf{r}\end{array}$ & $\begin{array}{c}\text { Total } \\
\text { (Monthly }\end{array}$ \\
\hline January & 32.6 & 4.57 & 31.92 & 0.53 & 11.53 & 10.84 & 19.6 & 28.84 & 140.42 \\
February & 25.79 & 4.64 & 25.82 & 0.60 & 12.04 & 14.73 & 23.6 & 28.64 & 135.87 \\
March & 25.84 & 5.85 & 27.99 & 0.64 & 14.48 & 13.26 & 21.17 & 32.43 & 141.66 \\
April & 25.12 & 5.40 & 26.32 & 0.43 & 14.13 & 12.19 & 14.35 & 24.75 & 122.65 \\
May & 33.84 & 6.31 & 31.94 & 0.44 & 15.04 & 14.17 & 19.34 & 29.2 & 150.28 \\
June & 54.02 & 5.56 & 38.94 & 0.41 & 16.19 & 18.95 & 20.84 & 29.65 & 184.55 \\
July & 45.06 & 6.32 & 33.57 & 0.45 & 14.83 & 14.95 & 16.17 & 24.95 & 156.29 \\
August & 50.99 & 10.52 & 41.97 & 0.54 & 16.41 & 19.35 & 19.33 & 34.89 & 194.00 \\
September & 35.79 & 7.05 & 29.76 & 0.59 & 13.39 & 17.9 & 16.82 & 32.39 & 153.7 \\
October & 33.96 & 9.85 & 28.90 & 0.36 & 13.05 & 29.91 & 17.78 & 43.16 & 177.01 \\
November & 35.17 & 16.58 & 35.02 & 0.59 & 19.27 & 34.95 & 23.49 & 63.49 & 228.56 \\
December & 31.18 & 3.54 & 33.34 & 0.67 & 17.72 & 30.21 & 26.07 & 53.72 & 196.45 \\
\hline Total (By & $\mathbf{4 2 9 . 3 6}$ & $\mathbf{8 6 . 1 9}$ & $\mathbf{3 8 5 . 4 9}$ & $\mathbf{6 . 2 5}$ & $\mathbf{1 7 8 . 0 8}$ & $\mathbf{2 3 1 . 4 1}$ & $\mathbf{2 3 8 . 5 6}$ & $\mathbf{4 2 6 . 1}$ & $\mathbf{1 9 8 1 . 4 4}$ \\
State) & & & & & & & & & $\mathbf{1}$ \\
\hline
\end{tabular}

Source: SWCorp's Solid Waste and Public Cleansing Management Corporation, (2016)

Table 2: The collection of recyclable waste weight based on waste types in 2016

\begin{tabular}{lcc}
\hline \multirow{2}{*}{ Type of Waste } & \multicolumn{2}{c}{ January to December 2016 } \\
\cline { 2 - 3 } & Weight $(\mathbf{K g})$ & Percent $(\boldsymbol{\%})$ \\
\hline Plastic & 605.25 & 30.55 \\
Paper & 809.74 & 40.87 \\
Iron & 225.4 & 11.38 \\
Aluminum & 7.2 & 0.36 \\
Glass & 198.11 & 10.00 \\
E-Waste & 11.3 & 0.57 \\
Others & 124.45 & 6.28 \\
\hline \multicolumn{1}{c}{ Overall } & $\mathbf{1 9 8 1 . 4 5}$ & $\mathbf{1 0 0}$ \\
\hline
\end{tabular}

Source: SWCorp's Solid Waste and Public Cleansing Management Corporation, (2016)

Following the above discussion and elaborations, the universities do not ask their citizens to care about the environment to create expected sustainability (Nuttall, 2013). The main challenge regarding environmental conservation is the awareness and perceptions among students themselves. There are not many people who think that maintaining the cleanliness all over the place could guarantee the success of the children in the future.
Therefore, the students should be increasing their understanding and level of awareness related the environmental hygiene management to maintain the sustainability for the convenience of all parties. Although there are people who manage environmental hygiene nearby faculties and residential colleges, there are still problems with endless waste in the surrounding areas. 


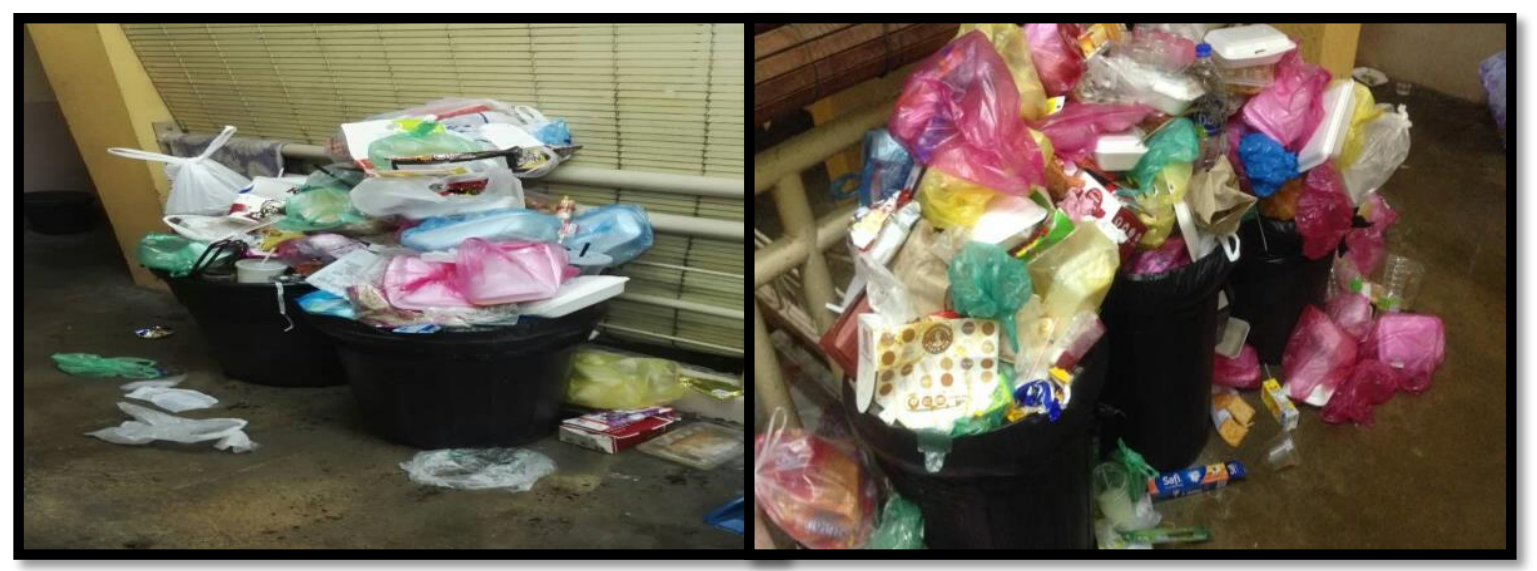

Figure 1: The pile waste made by the UMT residential college students

\section{Literature Review}

Level of awareness is an important aspect of environmental care. It is because high level of awareness on the environment would make individuals feel responsible for keeping cleanliness around their place. According to Berenguer (2007), the community has a high awareness of environmental issues but behaviour and environmental responsibility is still not the norm and this situation occurs in any country. Lack of awareness and responsibility for the environment will lead to the dumping of rubbish in the community.

In addition, Ridener (2007) argues that most students already have high environmental awareness. Nevertheless, when the behavior of 276 students were examined regarding their practice of environmental care, it was found to be at a weak level. This scenario was proven by many previous studies which found that there was a gap and weakness in the level of awareness and behavior of students on environmental sustainability in universities (Zurina \& Norjan, 2003; Mohd Yusoh, 2003; Azizan 2008; Wahidah et al. 2014).

Indeed this aspect of consciousness plays an important role in changing for the better. Previous studies found that the level of knowledge, attitudes, and awareness of students towards the environment was at a good level (Ruhaya 2001; Mohd Yusof et al., 2003; Ramli, 2003; Zurina \& Norjan, 2003; Ismail, 2005; Norjan et al., 2005; Norlila, 2007). However, the Department of Environment of Malaysia (2016) stated that the level of awareness on the environment of Malaysians had not yet reached a level comparable to other countries such as Japan, Denmark, and Germany. This is because the students were only sensitive to environmental issues directly affecting their life but the awareness to address the issue was at a minimum (Zurina \& Norjan, 2003).

\section{Materials and Methods}

This study was designed using the quantitative approach through cross-sectional data and was carried out in Universiti Malaysia Terengganu, involving students at UMT residential colleges. The sample comprised students aged 20 and above. A total of 100 students made up the sample, determined using the Slovin's formula (Slovin's, 1960) and collected randomly among students staying at UMT residential colleges. To achieve the objective of this study, two types of statistical analysis were used, namely descriptive and inferential statistics. Descriptive statistics involves the frequency and percentage while inferential statistics involves detailed analysis such as multiple linear regression analysis.

\section{Results and Discussion}

Prior to data analysis, the data underwent a cleaning process and the existence of outliers was checked to avoid bias responses in this study. A total of 120 respondents participated, but only data from 100 respondents could be used for future analysis. Table 3 shows the result of descriptive statistics. 
Table 3: The Result of Descriptive Statistics using Frequency and Percentage for Awareness among UMT Residential College Students

\begin{tabular}{|c|c|c|c|c|c|}
\hline \multirow[b]{2}{*}{ Item } & \multicolumn{5}{|c|}{ The Frequency and Percentage for the Awareness Responses } \\
\hline & $\begin{array}{l}\text { Strongly } \\
\text { Disagree }\end{array}$ & Disagree & Not sure & Agree & $\begin{array}{l}\text { Strongly } \\
\text { Agree }\end{array}$ \\
\hline Hygiene is important for students & 2 & 1 & 0 & 13 & 84 \\
\hline Moral value about hygiene & 14 & 9 & 23 & 37 & 17 \\
\hline Dirty environment affects the scenery & 3 & 6 & 0 & 17 & 74 \\
\hline Trash bins are enough & 7 & 22 & 20 & 35 & 16 \\
\hline Knowledge on recycling & 1 & 4 & 19 & 48 & 28 \\
\hline Do not waste trash everywhere & 3 & 8 & 0 & 42 & 47 \\
\hline $\begin{array}{l}\text { Knowledge of dormitory laws and } \\
\text { rules }\end{array}$ & 4 & 19 & 0 & 37 & 40 \\
\hline Dumping waste causes foul smell & 1 & 4 & 0 & 22 & 73 \\
\hline I clean the room every day & 1 & 4 & 22 & 43 & 30 \\
\hline $\begin{array}{l}\text { I will make sure waste does not } \\
\text { overflow from the trash }\end{array}$ & 1 & 5 & 15 & 37 & 42 \\
\hline $\begin{array}{l}\text { I will report to the University about } \\
\text { the waste dump }\end{array}$ & 2 & 9 & 39 & 32 & 18 \\
\hline
\end{tabular}

As can be seen in Table 3, on the moral values on hygiene, there were 54 percent of respondents who strongly agreed, while the rest gave the uncertain and disagreed responses, at 23 percent. On the statement "dirty environment affects the scenery", majority of respondents strongly agreed, at 91 percent, and only 9 percent expressed disagreement. For the question "trash bins are enough", 51 percent of the respondents strongly agreed, followed by 29 percent admitting strong disagreement and the remaining 20 percent expressing uncertainty in response to the question. With regard to the question on the concept of recycling, the majority agreed at 76 percent, 19 percent said they were unsure and 5 percent said they disagreed.

More than half of the respondents responded positively about not throwing away the rubbish and only 11 percent of the respondents chose strongly disagree response. For the question about knowledge of dormitory laws and rules, 77 percent strongly agreed and 23 percent strongly disagreed. Almost all respondents (95 percent) agreed that dumping waste causes foul smell and the rest, at 5 percent, strongly disagreed. For the item "I clean the room every day", majority of respondents chose Strongly Agree response, at 73 percent. 22 percent chose Unsure response and only 5 percent did not agree with the statement. About 79 percent of respondents agree with the statement "I will make sure waste does not overflow from the trash", while 15 percent said they were unsure and only 6 percent strongly disagreed. For the question "I will report to the University about the waste dump", 50 percent strongly agreed, 39 percent were uncertain and 11 percent strongly disagreed.

The result of analysis using multiple regression is presented in Table 4 below.

Table 4: The Result of Hypotheses Testing

\begin{tabular}{|c|c|c|c|c|c|}
\hline \multirow{2}{*}{ Model } & \multicolumn{2}{|c|}{$\begin{array}{l}\text { Unstandardized } \\
\text { Coefficients }\end{array}$} & \multirow{2}{*}{$\begin{array}{c}\text { Standardized } \\
\text { Coefficients } \\
\text { Beta }\end{array}$} & \multirow{2}{*}{$\mathbf{t}$} & \multirow{2}{*}{ Sig. } \\
\hline & B & $\begin{array}{l}\text { Std. } \\
\text { error }\end{array}$ & & & \\
\hline Constant & 1.162 & 0.682 & & 1.704 & 0.092 \\
\hline Level of awareness & 0.403 & 0.186 & 0.235 & 2.173 & 0.032 \\
\hline Hygiene practices & 0.151 & 0.125 & 0.123 & 1.207 & 0.231 \\
\hline Level of involvement & 0.131 & 0.095 & 0.148 & 1.382 & 0.170 \\
\hline
\end{tabular}

Dependent Variable: Environmental Hygiene

The results of the analysis presented in Table 4 showed that there three independent variables were used in this study, namely hygiene practice, awareness and involvement levels, and the dependent variable was environmental hygiene. The result of the regression analysis indicated that the level of awareness had significant influence on the environmental hygiene, with the beta value of 0.235 and significant at the 5 percent 
level. This means that, assuming the level of awareness increases by 1 percent, the environmental hygiene will increase by as much as 23.5 percent. The similar finding was reported by Berenguer, (2007) who found that the community had a high level of awareness of the environmental issues but behaviour and environmental responsibility still did not become the norm and this situation occurred in several countries. In addition, this finding reinforces the theory of action which claims that human action arises from its own consciousness as a subject and from the external situation within its position as an object. As subjects, humans act or behave to achieve certain goals. Besides that, this study also found that hygiene practice and level of involvement did not have significant influences on environmental hygiene.

\section{Conclusion}

Environmental hygiene today is one of the main focus

\section{References}

Ali, H., Ali, N., Ibrahim, M., Bee, A., Yaakob, S., \& Mohamad, N. J. (2010). Pengguna dan kitar semula ke arah kelestarian alam sekitar. In Prosiding Seminar Kebangsaan MACFEA Ke (Vol. 14, pp. 393-406).

Ali, H., Dermawan, D., Ali, N., Ibrahim, M., \& Yaacob, S. (2017). Masyarakat dan amalan pengurusan sisa pepejal ke arah kelestarian komuniti: Kes isi rumah wanita di Bandar Baru Bangi, Malaysia (Society and the practise of solid waste management towards sustainable community: The case of female households in Bandar Baru Bangi, Malaysia). Geografia-Malaysian Journal of Society and Space, 8(5).

Dincer, I. (2000). Renewable energy and sustainable development: a crucial review. Renewable and sustainable energy reviews, 4(2), 157-175.

Jahi, J. M. (2001). Pengurusan alam sekitar di Malaysia: dari Stockholm ke Rio de Jainero dan seterusnya. Penerbit Universiti Kebangsaan Malaysia.

JPSPN. (2013). Survey on Solid Waste Composition, Characteristics \& Existing Practice of Solid Waste Recycling in Malaysia Final Report. Kementerian Kesejahteraan Bandar, Perumahan dan Kerajaan Tempatan.

Maps, G. (2017). Lokasi Gong Badak. Retrieved from peta terengganu: https://www.googlemaps.com.my/maps, November 2017. not only in Malaysia but all over the world as it is one of the elements in sustainable development goals (SDG). In line with the issue of environmental hygiene, using the results and findings of this study, we conclude that the level of awareness is the most influential factor and has significant positive relationship with environmental hygiene. However, the hygiene practice and involvement are two elements that cannot be interpreted as factors that influence environmental hygiene. Although this study found that these two factors did not significant influences towards environmental hygiene, it does not mean these factors are not important. Thus, based on this study, we recommend future studies with more sample and testing by group through multiple group analysis (MGA-Partial Least Square). In addition, we suggest that stakeholders of UMT increase the hygiene practice and involvement among young generation to increase their level of awareness on environmental hygiene.

Mohd Yusop bin Abd Hadi, Jailani bin Mohd Yunos \& Ahmad bin Esa. 2003. (2003). Meningkatkan Pengetahuan, Amalan dan Sikap terhadap Pendidikan Alam di kalangan Pelajar. Prosiding Seminar Kebangsaan Pengurusan Persekitaran. Bangi :Universiti Kebangsaan Malaysia .

Muhd Ibrahim Muhamad Damanhuri, Durairaj Ehambron, Marlizah Yusuf. (2016). Tahap Kesedaran Dan Amalan Pendidikan Alam Sekitar Dalam Kalangan Pelajar Tingkatan 4 aliran sains di daerah Hulu Selangor.

Negara, J. P. S. P. (2012). Lab Pengurusan Sisa Pepejal.

Norjan Yusuf, Nur Ibtisam Ibrahim, Rohana Sulaiman \& Rohayati Mamat. (2005). Tinjauan Pengetahuan dan Kesedaran Alam Sekitar di kalangan Pelajar Orang Asli. Prosiding Seminar Kebangsaan Pengurusan Persekitaran. Bangi :Universiti Kebangsaan Malaysia.

Norjan Yusuf, Nur Ibtisam Ibrahim, Rohana Sulaiman \& Rohayati Mamat. (2005 ). Tinjauan Pengetahuan dan Kesedaran Alam Sekitar di kalangan Pelajar Orang Asli. Prosiding Seminar Kebangsaan Pengurusan Persekitaran .Bangi :Universiti Kebangsaan Malaysia.

Nurul Izzati Majunit \& Zaiton Iksan. (2017). Tahap Kesedaran dan Tingkah Laku Pelajar Melalui Kajian Aplikasi Kendiri Alam Sekitar (KAKAS).

Omer, A. M. (2008). Energy, environment and sustainable development. Renewable and sustainable energy reviews, 12(9), 2265-2300. 
Seow Ta Wee, Jamaluddin Md Jahi \& Indera Syahrul Mat Radzuan, (2010). Tingkah Laku Masyarakat Terhadap Program Kitar Semula: KajianKes Di Daerah Batu Pahat. Retrieved from http://sssums.files.wordpress.com/2007/09/tingkahlakumasyarakat-terhadap-program-kitar-semulakajian-kes-di-daerah-batu-pahat.pdf. 19 November 2015

United Nation (2011) Agenda 21, Chapter 4: Changing Consumption. Retrieved from MIT Press Cambridge, Massachusetts London England: http://www.un.org/esa/dsd/agenda21/res_agenda21_ 04.shtml, 12 November 1).

West, L. (2010, january 2). What Can You Do To Protect and Preserve the Environment? . Retrieved from http://environment.about.com/od/greenlivingdesign/ u/what to do.htm 22 November 2017.

Zurina Mahadi \& Norjan Yusof. (2003). Kesedaran Alam Sekitar: Tinjauan Awal di kalangan kalangan Pelajar Universiti Kebangsaan Malaysia. Prosiding Seminar Kebangsaan Pengurusan Persekitaran. Bangi: Universiti Kebangsaan Malaysia. 